\section{ENDOTHELIAL NITRIC OXIDE CONCENTRATIONS IN THE SALIVA OF JIU-JITSU ATHLETES}

\author{
CONCENTRAÇÕES DE ÓXIDO NÍTRICO ENDOTELIAL NA SALIVA DE ATLETAS DE JIU-JITSU
}

CONCENTRACIONES DEÓXIDO NITTRICO ENDOTELIAL EN LA SALIVA DE ATLETAS DE JIU-JITSU

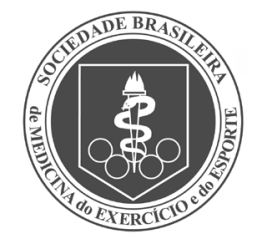

Original Article

Artigo Original Artículo Original

\begin{abstract}
Nestor Persio Alvim Agricola' (DD (Physical Education Professional) Lidia Andreu Guillo2 (ID) (Chemist)

1. Universidade Federal de Jataí, Academic Unit of Health Sciences, Department of Physical Education, GO, Brazil.

2. Universidade Federal de Goiás, Institute of Biological Sciences, Department of Molecular Biology, GO, Brazil.
\end{abstract}

\section{Correspondence:}

Nestor Persio Alvim Agricola. Rua Voluntários da Pátria, 1132, Vila Fátima, Jataí, GO, Brazil. 75803-100. nestoralvim@hotmail.com

\begin{abstract}
Introduction: This article discusses the production of nitric oxide under the influence of sport-specific physical training, measured by the salivary nitrite of Jiu-Jitsu athletes. Objectives: To verify the potential of the sport to produce optimal levels of nitric oxide stimulated by exertion, and to quantify training-related nitric oxide concentrations. Method: The study participants were 14 volunteer athletes from the Tatame project (extension project), who were monitored for nine months in their training routine, providing samples of unstimulated saliva. Samples were collected each month, in three periods of the day: in the morning upon waking, immediately before training, and immediately after training. Salivary nitrite was quantified by the colorimetric Griess assay. Training heart rates were also monitored in order to establish training intensity. Results: Mean monthly salivary nitrite levels showed a significant correlation with mean monthly heart rates, suggesting that salivary nitrite responds to training. However, salivary nitrite concentrations measured immediately after training were always lower than in the pre-training period. Conclusion: The post-training reduction in concentrations was due to the nature of the sport studied, since because it involves a fight, the intense sympathetic stimulation inhibited salivary gland activity and irrigation, preventing salivary nitrite from producing an increase in circulating nitric oxide. Level of evidence IV; Case series.
\end{abstract}

Keywords: Nitric oxide; Physical exertion; Saliva; Health.

\section{RESUMO}

Introdução: Este artigo discute a produção de óxido nítrico sob interferência do treinamento físico esportivo, medida pelo nitrito salivar em atletas de Jiu-Jitsu. Objetivos: Verificar as potencialidades da modalidade na produção de níveis ideais de óxido nítrico estimulado pelo esforço e quantificar as concentrações de óxido nítrico relacionadas com o treinamento. Métodos: O estudo teve a participação de 14 atletas voluntários do Projeto Tatame (projeto de extensão), que foram acompanhados por nove meses em sua rotina de treinamento e forneceram amostras de saliva não estimulada. Foram coletadas amostras a cada mês, em três períodos do dia: pela manhã ao acordar, imediatamente antes do treino e imediatamente após o treino. O nitrito salivar foi quantificado pelo método colorimétrico de Griess. Também foram monitoradas as frequências cardíacas de treinamento a fim de se estabelecer a intensidade do treinamento realizado. Resultados: As médias mensais de nitrito salivar demonstraram correlação significativa com as médias mensais de frequência cardíaca, dando indícios de que o nitrito salivar responde ao treinamento. Contudo, as concentrações de nitrito salivar medidas imediatamente após o treinamento sempre eram menores com relação ao período anterior do treino. Conclusão: A redução da concentração depois do treinamento deveu-se à natureza da modalidade estudada, visto que, por ser uma luta, a forte carga de estimulação simpática inibiu a a tividade das glândulas salivares, bem como sua irrigação, impedindo que o nitrito salivar produzisse aumento do óxido nítrico circulante. Nível de evidência IV; Série de casos.

Descritores: Óxido nítrico; Esforço físico; Saliva; Saúde.

\section{RESUMEN}

Introducción: Este artículo a naliza la producción de óxido nítrico bajo la influencia del entrenamiento físico deportivo, medida por el nitrito salival de atletas de Jiu-Jitsu. Objetivos: Verificar el potencial de la modalidad en la producción de niveles ideales de óxido nítrico estimulado por el esfuerzo y cuantificar las concentraciones de óxido nítrico relacionadas con el entrenamiento. Métodos: El estudio contó con la participación de 14 atletas voluntarios participantes del Proyecto Tatame (proyecto de extensión) a quienes se les dio seguimiento durante nueve meses en su rutina de entrenamiento y proporcionaron muestras de saliva no estimulada. Se recolectaron muestras cada mes, en tres períodos del día: en la mañana al despertar, inmediatamente antes del entrenamiento e inmediatamente después del entrenamiento. El nitrito salival se cuantificó por el método colorimétrico de Griess. Las frecuencias cardiacas de entrenamiento se monitorearon para establecer la intensidad del entrenamiento realizado. Resultados: Los promedios mensuales de nitrito salival mostraron una correlación significativa con los promedios mensuales de frecuencia cardiaca, lo que indica que el nitrito salival responde al entrenamiento. Sin embargo, las concentraciones de nitrito salival medidas inmediatamente después del entrenamiento siempre fueron más bajas en comparación con el perío do anterior al entrenamiento. Conclusión: 
La reducción de la concentración después del entrenamiento se debió a la naturaleza de la modalidad estudiada, ya que, por ser una lucha, la fuerte carga de estimulación simpática inhibió la actividad de las glándulas salivales, así como su irrigación, evitando que el nitrito salival produjera aumento de óxido nítrico circulante.

Nivel de evidencia IV; Serie de casos.

Descriptores: Óxido nítrico; Esfuerzo físico; Saliva; Salud.

\section{INTRODUCTION}

Nitric oxide (NO) is an inorganic, gaseous molecule with a short half-life, which has an unpaired electron in its last layer, making it a highly reactive ionic molecule that combines with oxygen and some transition metals. It is a free radical that can serve as both an oxidizing and reducing agent. ${ }^{1}$

The investigation into a determinant vasodilator factor in the relaxation of the smooth muscles of the vascular endothelium led to the hypothesis of the existence of Endothelial-Derived Relaxing Factor (EDRF). ${ }^{2}$ It was later discovered that the mechanism whereby EDRF produced muscle relaxation present in the endothelium was mediated by cyclic guanosine monophosphate (cGMP), ${ }^{3}$ and this led to the conclusion that $\mathrm{NO}$ was the molecule common to vasodilator processes. ${ }^{4}$

$\mathrm{NO}$ is involved in a range of reactions in the human body and has the ability to be both beneficial and potentially toxic. It is produced endogenously by different types of cells. It is the main cytotoxic mediator of immune cells, and the precursor to nitrites and nitrates excreted by macrophages in specific immune responses. ${ }^{5}$ The cytotoxic potential of NO appears timely as it is produced in significant amounts during the immune response and causes lethal oxidative damage to target cells. ${ }^{6}$ Besides acting directly on vasodilation, it also has the property of inhibiting platelet aggregation, preventing thrombi formation. ${ }^{7}$

\section{Synthesis and action}

Nitric oxide is produced by the nitric oxide synthase (NOS) enzymes, which are hemeproteins divided into three isoforms that have the same catalytic mechanism and use the same substrates, cofactors, and cosubstrates. Isoform 3 is endothelial nitric oxide synthase (eNOS), which produces NO continuously in the endothelium under baseline conditions. By producing greater friction (shear stress), the increased blood flow prompts eNOS to increase NO production. ${ }^{8}$

After being produced in the endothelial cells, $\mathrm{NO}$ migrates into the smooth muscle cell, where it will exert vasodilator action. The action of $\mathrm{NO}$ in the vasodilation process involves interaction with guanylate cyclase (GC), thereby activating this enzyme. The activated GC will catalyze the guanosine triphosphate (GTP) molecule, causing it to lose two phosphate groups and become cyclic guanosine monophosphate (cGMP). The increase in the amount of cGMP will lead to muscle cell relaxation through the increase in intracellular calcium concentration. ${ }^{9}$

After the reaction, the remaining $\mathrm{NO}$ leaves the muscle cell and migrates into the bloodstream, where it will penetrate platelets and red blood cells. NO that penetrates red blood cells is eliminated in the form of nitrate and nitrite.

\section{Nitric oxide and exercise}

The number of weekly exercise sessions, exercise time and intensity interfere with the hypotensive effects. ${ }^{10,11}$ However, it appears that the effect of blood pressure control occurs more markedly in exercise of moderate intensity, around 50 to $65 \%$ of maximum intensity, ${ }^{12}$ and that physical activities involving large muscle groups also stand out in comparison to more localized exercises. ${ }^{13}$
According to a recent study, ${ }_{14} \mathrm{NO}$ acts on the activation of mitochondrial biogenesis of the skeletal muscle, thereby improving myocyte respiration, and interferes directly in the supply of nutrients and oxygen of the myocyte through blood flow regulation. Long-term exposure of muscle cells to NO triggers mitochondrial biogenesis involving CGMP activation. ${ }^{14}$ Aerobic physical exercise activates the release of neutrophic factors and promotes angiogenesis, facilitating neurogenesis and synaptogenesis, which in turn improve cognitive functions. ${ }^{15}$

In the field of physical activity, saliva is used in the effort to establish a safe and reliable protocol for testing the body's physiological responses to exertion, and defining exercise control parameters that are non-invasive. ${ }^{16}$

Some research studies report that physical exercise does not produce significant variations in salivary nitrite concentrations, claiming that there is no association between these two variables. ${ }^{17-19}$ Conversely, other studies report significant variations in salivary nitrite concentrations from physical exercise. ${ }^{20-22}$ These studies report an increase in salivary nitrite concentrations after exercise, corroborating the hypothesis that exercise, by potentiating the production of circulating NO, also expresses this production in saliva.

Jiu-Jitsu is a sport that requires considerable endurance capacity, but also pure explosive power. We must bear in mind that the biochemical effects of exertion, and more specifically, those related to the control of blood pressure and the cardiovascular and immune systems, constitute a fertile field of study. Thus, the study of specific characteristics of a sport that has not yet been studied in depth was the main motivating force behind this work.

NO has been considered a factor of athletic sports performance as it improves the blood supply to the muscles, boosting the delivery of nutrients and gas exchanges. Accordingly, the objective of this study is to discuss nitric oxide in the human body based on the variations of this compound induced by Jiu-Jitsu training, in its particularities of exertion and intensity, and to test the viability of saliva as a safe quantification marker that can express variations in endothelial nitric oxide.

\section{MATERIALS AND METHODS}

This study was approved by the Institutional Review Board of Universidade Federal de Goiás under opinion 692.581. All the volunteers signed the Informed Consent Form (ICF).

The study is of the longitudinal measurement type, and involved the participation of 14 volunteers, Jiu-Jitsu athletes with at least two years of experience, competitors in regional and national events, with an average age of 27 ( \pm 4.56 ) years. The athletes were monitored for nine months in their annual training cycle. A single day was chosen in each month of follow-up for the collection of saliva samples. Salivation was not stimulated, and samples were collected in the morning (morning), before the training session (afternoon), and after the training session (evening). Each sample consisted of $2 \mathrm{ml}$ of saliva in cryosterilized tubes.

The dosage of nitric oxide was obtained through the Griess reagent system. The nitrite detection kit produced by Molecular Probes ${ }^{\circledR}$ (Eugene, USA), was used in the study. A 96-well flat-bottomed microplate was used to quantify duplicate samples. Standards were obtained by diluting sodium nitrite in five different concentrations: $150 \mu \mathrm{M}, 100 \mu \mathrm{M}, 50 \mu \mathrm{M}$, $10 \mu \mathrm{M}$ and $5 \mu \mathrm{M}$, to obtain the standard curve and the linear regression 
equation. The reading of the microplates with a $550 \mathrm{~nm}$ wavelength filter provided absorbance values that were applied to the linear regression equation of the standard curve to obtain nitrite concentration values. A total of eight microplates were produced. After the experiment, the samples were discarded as biological material.

Throughout the monitored training period, the athletes' heart rates were monitored in order to reach a conclusion on training intensity. Every week, on a specific day, training was carried out using a heart rate monitor that provided the mean individual heart rate in the training session. This data was used to calculate the mean monthly heart rate.

\section{Statistical analysis}

The data obtained underwent statistical analysis. ${ }^{23,24}$ The tests used were: Shapiro-Wilk test for normality, Pearson's correlation test, one-way analysis of variance (one-way ANOVA) with Tukey's post-hoc test, and the Kruskal-Wallis test for comparison of data groups that did not show normal distribution.

\section{RESULTS}

The salivary nitrite concentration values found were obtained from the arithmetic mean among the samples tested in duplicate. The acceptable experimental error was approximately $15 \%$ of variation between duplicates. The data obtained were grouped and treated statistically in two ways:

1. Grouped month by month and expressed as a single monthly mean; 2. Grouped in the morning, afternoon and evening, expressing overall mean and month-to-month mean.

In Table 1, the data are expressed in mean \pm standard error with unit of measurement in micromoles (Table 1). The table expresses the mean of the group of athletes participating in each sample collection.

The result of the ANOVA test was significant with a p-value of 0.0208 . The Tukey post-hoc test, between months, showed significance only between months 6 and 9 , with a $p$-value of 0.00246 . The monthly mean nitrite concentrations presented two peaks, in month 2 and in month 6 (Figure 1), showing similarity with mean monthly heart rates, indicative of training intensity. (Figure 2)

Table 1. Mean nitrite concentrations of the group of athletes in $\mu \mathrm{M}$.

\begin{tabular}{c|c|c|c|c}
\hline Collections & Morning & Afternoon & Evening & Mean \\
\hline Month 1 & $31.99 \pm 8.29$ & $56.23 \pm 16.31$ & $35.62 \pm 5.78$ & $42.91 \pm 7.69$ \\
\hline Month 2 & $49.10 \pm 15.67$ & $66.10 \pm 10.46$ & $42.59 \pm 12.20$ & $52.60 \pm 7.72$ \\
\hline Month 3 & $30.62 \pm 8.72$ & $58.54 \pm 15.26$ & $40.9 \pm 8.38$ & $43.36 \pm 8.38$ \\
\hline Month 4 & $19.31 \pm 13.15$ & $57.14 \pm 14.93$ & $45.93 \pm 9.53$ & $40.80 \pm 8.46$ \\
\hline Month 5 & $29.24 \pm 12.94$ & $57.07 \pm 13.0$ & $38.93 \pm 11.99$ & $41.68 \pm 9.32$ \\
\hline Month 6 & $30.57 \pm 14.41$ & $89.44 \pm 18.57$ & $80.54 \pm 26.09$ & $68.90 \pm 13.4$ \\
\hline Month 7 & $30.03 \pm 12.23$ & $47.17 \pm 15.15$ & $41.78 \pm 9.93$ & $39.66 \pm 8.50 \dagger$ \\
\hline Month 8 & $31.53 \pm 18.16$ & $48.05 \pm 11.27$ & $31.42 \pm 14.0$ & $37.70 \pm 7.92$ \\
\hline Month 9 & $11.54 \pm 6.67$ & $23.35 \pm 5.11$ & $29.59 \pm 8.65$ & $21.64 \pm 4.51$ \\
\hline Mean & $29.14 \pm 4.13$ & $55.75 \pm 4.77^{*}$ & $42.65 \pm 4.17$ & $42.52 \pm 4.36$ \\
\hline
\end{tabular}

*Significant difference in comparison to the morning with $p<0.05$. S Significant difference with $p<0.05$.

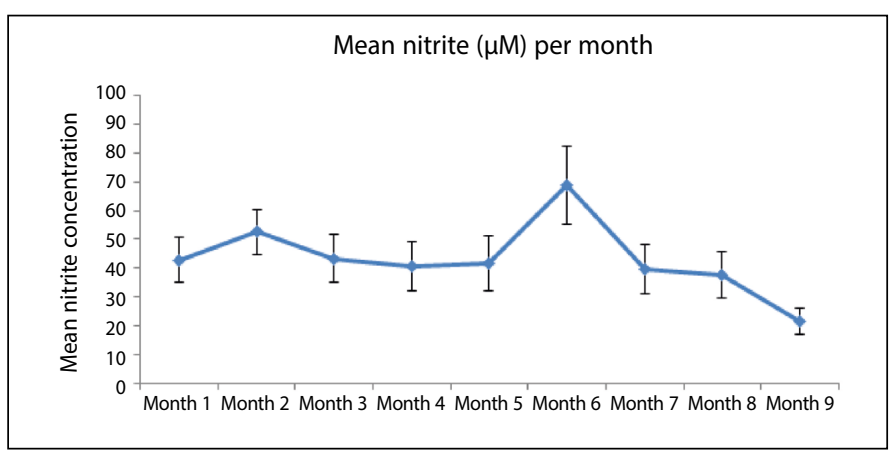

Figure 1. Mean monthly salivary nitrite concentrations.
Figures 1 and 2 show the relationship between salivary nitrite and training intensity. The monthly means of nitrites had a strong correlation with the heart rate data. Pearson's correlation test was 0.7409 with a $\mathrm{p}$-value of 0.0379 , showing that variations in salivary nitrite throughout the training year are influenced by the intensity of the training performed. During the follow-up period of the group of athletes, there were two competitions in which part of the athletes participated. The competitions were in the last week of month 2, and in the last week of month 6 .

The mean of each period depicts a specific graph that is repeated month by month. Lower and more homogeneous values were expected for the morning collections, due to low activity, with an increase in values for the afternoon before training, and an even greater increase for the evening, in response to training.

In observing the data grouped in morning, afternoon and evening, we noted a specific behavior. As shown in Figure 3, the distribution of data forms a pattern that varies little from month to month, and that amounts to low values in the morning, high values in the afternoon before training, and a drop in values right after training.

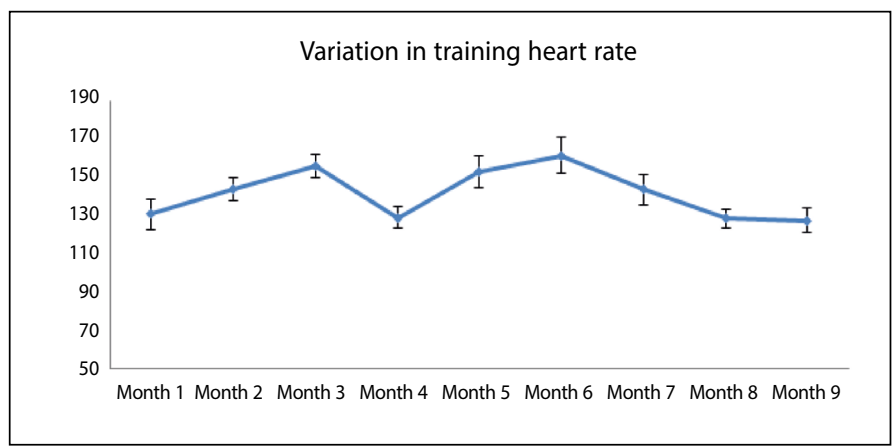

Figure 2. Mean monthly training heart rates.

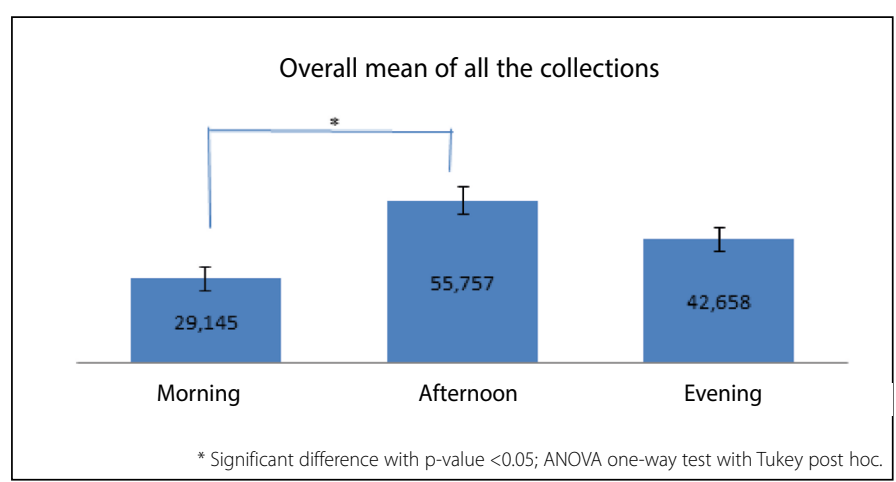

Figure 3. Overall mean morning, afternoon, and evening collections.

\section{DISCUSSION}

Salivary nitrite is a compound that is susceptible to a series of variables which can interfere with its concentration, making the task of associating it with a specific variable somewhat difficult. The intriguing fact present in the data obtained was that, contrary to expectations, nitrite concentrations decreased after the training session.

The month-by-month follow-up of Jiu-Jitsu athletes for nine months enabled us to verify the statistical evidence that salivary nitrite is influenced by physical training and accompanies variations in intensity, as shown by Figures 1 and 2. Based on these data, it can be concluded that salivary nitrite expresses the intensity of the training performed, following its variations.

Another factor that indicates the susceptibility of salivary nitrite to physical training was the acute response to training shown in the comparison between pre- and post-training results. The response to training verified by a drop in salivary nitrite concentrations was repeated in eight of the nine months of follow-up, as shown in Table 1. 
The increase in NO production by eNOS, after physical exercise, is an automatic mechanism whose main factor is shear stress. NO circulating in the bloodstream relaxes the smooth muscles of the endothelium. Part of this substance penetrates hemoglobin and reacts with iron, is converted to nitrite, and spreads throughout the body. The salivary gland receives nitrite from the bloodstream, along with water, and excretes it. 20-22 Therefore, it should express an increase in concentration and not a decrease, as was the case here. As can be seen, other arguments are needed to explain salivary nitrite variations in athletes.

Salivation is regulated by neural stimuli, mainly parasympathetic signals. Sympathetic stimulation reduces glandular activity and salivary volume. The parasympathetic signals that induce salivation also act on the vasodilation of the glandular region. The aqueous portion of saliva originates from local capillary irrigation, passing from the bloodstream to the secretory cells by diffusion. ${ }^{16}$ Nitric oxide in saliva is rapidly reduced to nitrite by the action of the enzyme nitrate reductase. ${ }^{25}$ Nitrite can also originate from the bloodstream together with the aqueous component of blood, which reaches the secretory cells of the salivary glands, expressing, in saliva, the variations that this compound has in the bloodstream. ${ }^{18}$

Studies have shown that NO production is largely influenced by predominant nerve stimulation, in which parasympathetic activity stimulates production, whereas sympathetic activity is associated with low production of $\mathrm{NO}^{26}$ Predominantly sympathetic stimulation tends to reduce endothelial $\mathrm{NO}$ concentrations and even cause an increase in blood pressure. ${ }^{26}$

The autonomic nervous system is composed of the parasympathetic branch and the sympathetic branch, whose messengers are acetylcholine and norepinephrine, which transmit messages throughout the body. Sympathetic action enables the body to respond to situations of stress and tension such as fight or flight reactions, and is accompanied by effects such as heart rate acceleration and increased blood pressure. ${ }^{27}$ This action modulates the blood flow distribution, directing a greater flow to the organs and systems involved in the body's generic alarm reaction.
Jiu-Jitsu training sessions always end in an actual fight. Athletes face their opponents in matches lasting six to eight minutes. These matches are accompanied by stress and anxiety, since they are real fights. Significant sympathetic stimulation occurs at this time. The production of saliva by the salivary glands is inhibited, as is the blood supply to these glands.

Feelings of anxiety about the fight lead to significant sympathetic stimulation in athletes, which causes transitory inhibition of gland activity, producing a decrease in nitrite concentrations. The same effect was confirmed in students preparing for their school exams. ${ }^{28}$ In the study mentioned here, it was ascertained that the sympathetic tonic response to school test/examination anxiety brought about a reduction in glandular activity with a decrease in salivary volume and in NO concentrations, an effect that was normalized 24 hours after the exam.

\section{CONCLUSION}

Studies on nitric oxide are varied, divergent, and largely inconclusive, showing the need to study this compound further and in depth. Salivary nitrite responds to Jiu-Jitsu sports training, and promotes sufficient shear stress to generate an increase in NO production. This increase is expressed in saliva, but is influenced by other factors that may mask this expression. As the sport is accompanied by a state of stress and anxiety, like in fights, the quantification of salivary nitrite concentrations is compromised by the sympathetic stimulus and, in this situation, the salivary nitrite does not express the acute increase in the production of circulating NO.

Other protocols could potentially provide values that express an increase in circulating NO. Although the objective of this study was to quantify the influence of specific Jiu-Jitsu training on nitric oxide concentrations, the finding is deemed important, since we verified the decisive interference of a variable in this quantification. However, further studies are required in order to establish the interactions of $\mathrm{NO}$ with the different systems of the human body and with external stimuli.

All authors declare no potential conflict of interest related to this article

AUTHORS' CONTRIBUTIONS: Each author made significant individual contributions to this manuscript. NPAA and LAG: contributed equally and effectively to the preparation of the article. Substantial contribution to the conception, design, acquisition, analysis and interpretation of data, writing and critical review of its intellectual content, and final approval of the manuscript version.

\section{REFERENCES}

1. Cerqueira NF, Yoshida WB. Óxido nítrico: revisão. Acta Cir Bras. [serial online] 2002;17(6):417-23.

2. Furchgott RF, Zawadzki JV. The obligatory role of endothelial cells in the relaxation of arterial smooth muscle by acetylcholine. Nature. 1980;288(5789):373-6.

3. Rapaport RM, Murad F. Agonist induced endothelium-dependent relaxation in rat thoracic aorta may be mediated throught cyclic GMP. Circ Res. 1983;52(3):352-7.

4. Dusse LM, Vieira LM, Carvalho MG. Nitric oxide revision. J Bras Patol Med Lab. 2003;39(4):343-50.

5. Snyder SH, Bredt DS. Biological roles of nitric oxide. Sci Am. 1992;266(5):68-77.

6. Barreto RL, Correia CR, Muscará MN. Óxido nítrico: propriedades e potenciais usos terapêuticos. Quim Nova. 2005;28(6):1046-54

7. Flora Filho R, Zilberstein B. Óxido nítrico: o simples mensageiro percorrendo a complexidade. Metabolismo, síntese e funções. Rev Ass Med Bras. 2000;46(3):265-71.

8. Murrel GA, Dolan MM, Jang D, Szabo C, Warren RF, Hannafin JA. Nitric oxide: an important articular free radical. J Bone Joint Surg. 1996;78(2):265-74

9. Conger JD. Endothelial regulation of vascular tone. Hosp Pract. 1994;29(10):117-26.

10. Hamer M. The anti-hypertensive effects of exercise: integrating acute and chronic mechanisms. Sports Med. 2006;36(2):109-16.

11. Brum PC, Da Silva GJ, Moreira ED, Ida F, Negrão CE, Kriger EM. Exercise training increases baroreceptor gain sensitivity in normal and hypertensive rats. Hypertension. 2000;36(6):1018-22.

12. Forjaz CL, Santaella DF, Rezende LO, Barreto AC, Negrão CE. A duração do exercício determina a magnitude e a duração da hipotensão pós-exercício. Arq Bras Cardiol. 1998;70(2):99-104.

13. Brandão AF, Martins-Pinge MC. Nitric oxide alteration in the cardiovascular function by exercise training. Semina Cienc Biol Saude. 2007;28(1):53-68

14. Dyakova EY, Kapilevich LV, Shylko VG, Popov SV, Anfinogenova Y. Physical exercise associated with NO production: signaling pathways and significance in health and disease. Front Cell Dev Biol. 2015;3:19.

15. PaillardT, Rolland Y, Barreto PS. Protective effects of physical exercise in alzheimer's disease and parkinson's disease: a narrative review. J Clin Neurol. 2015;11(3):212-9.

16. Zuardi LR. Concentrações salivares, sanguíneas e plasmáticas de óxido nítrico em pacientes com doença periodontal antes e depois do tratamento periodontal não cirúrgico. 2012. Dissertação [Mestrado] Ribeirão Preto: Universidade de São Paulo (USP);2012.

17. Clodfelter WH, Basu S, Bolden C, Santos PC, King SB, Kim-Shapiro DB. The relationship between plasma and salivary NOx. Nitric Oxide. 2015:47:85-90

18. González D, Marquina R, Rondón N, Rodríguez-Malaver AJ, Reyes RA. Effects of aerobic exercise on uric acid, total antioxidant activity, oxidative stress, and nitric oxide in human saliva. Res Sports Med. 2008;16(2):128-37.

19. Zambrano JC, Marquina R, Sulbarán N, Rodríguez-Malaver AJ, Reyes RA. Aerobic exercise reduced oxidative stress in saliva of persons with down syndrome. Res Sports Med. 2009;17(3):195-203.

20. Diaz MM, Bocanegra OL, Teixeira RR, Soares SS, Espindola FS. Salivary nitric oxide and alpha-amylase as indexes of training intensity and load. Int J Sports Med. 2013;34(1):8-13.

21. Panossian AG, Oganessian AS, Ambartsumian $M$, Gabrielian ES, Wagner $H$, Wikman G. Effects of heavy physical exercise and adaptogens on nitric oxide content in human saliva. Phytomedicine. 1999;6(1):17-26.

22. Moraes JF. Associação entre nível de atividade física, nitrito salivar e fatores de risco cardiovascular em adolescentes portadores de variantes comuns dos genes FTO e ECA. 2014. Tese [Doutorado]. Brasília: Universidade Católica de Brasília (PUC); 2014

23. Callegari-Jaques SM. Bioestatística: princípios e aplicações. Porto Alegre: Artmed; 2007.

24. Approbato M. Manual prático de metodologia científica. Goiânia: Cir/Funape; 2010

25. Takahama U, Hirota S, Takayuki O. Detection of nitric oxide and its derivatives in human mixed saliva and acidified saliva. Methods Enzymol. 2008;440:381-96

26. Rossi BR, Mazer D, Silveira LC, Jacinto CP, Di Sacco TH, Blanco JH, et al. Physical exercise attenuates the cardiac autonomic deficit induced by nitric oxide synthesis blockade. Arq Bras Cardiol. 2009;92(1):31-8

27. Bear MF, Connors BW, Paradiso MA. Neuroscience: exploring the brain. Baltimore: Williams \& Wilkins. 1996. $666 \mathrm{p}$.

28. Minasian SM, Gevorkian ES, Daian AV, Ambartsumian MK Change in salivary nitric oxide levels in students in the examinational period. Gig Sanit. 2007;(4):79-81 